Пищик В.И.

\title{
Типология ментальности советских и постсоветских поколений
}

Представлено исследование типов ментальности советского, переходного и постсоветского поколений. Анализируются взгляды на типологию ментальности и методические подходы к ней. Рассмотрены результаты исследования ценностных оснований, сочиальныхустановок, представлений о своем Я, особенностей отношений и типов ментальности советских, постсоветских и переходных поколений

Ключевые слова ментальность, трансформация ментальности, типы ментальности, советское, переходное и постсоветское поколения, традиционная, инновационная ментальности

\section{Постановка проблемы}

В современном быстроменяющемся мире, когда наблюдается потеря социальных ориентиров развития молодого поколения, стоит остро проблема поколенческой разобщенности. Поэтому так актуальны сравнительные исследования типов ментальности поколений в изменяющемся обществе. Проблема типологии ментальности была отражена в ранних зарубежных исследованиях Ф. Броделя, Ф. Грауса, Ж. Дюби, Л. Леви-Брюля [5, 7, см. по 20], но касалась преимущественно стабильных структурных элементов ментальности и описания изменений артефактов культур прошлого. В современных отечественных (К.А. Абульханова, Г.В. Акопов, Г.М. Андреева, А.В. Брушлинский, И.Г. Дубов, Б.А. Душков, З.И. Левин, Т.В. Иванова, В.Ф. Петренко, В.Е. Семенов, В.А. Шкуратов и др.) и зарубежных (Дж.В. Берри, П.Р. Дассена, М.Х. Сигала, А.Х. Пуртинги, Г.К. Триандиса, Д. Филда и др.) исследованиях изучается структура ментальности, но нет единого мнения, что относить к ее элементам, показано влияние консервативных элементов ментальности на становление ее типов, но в меньшей степени ее динамических элементов.

Данная проблема определила цель нашего исследования - выявить и сравнить типы ментальности, представленные у поколений советских, переходных и постсоветских поколений. При этом ментальность мы определяем как сложную систему, которая интегрируется религиозной, этнической и социальной системами общества. Основу ментальности составляет согласованность доминирующих, нормативно закрепленных систем значений, смыслов и ценностей образа мира поколения, проявляющихся в его жизненном мире.

\section{Типологии ментальности}

Существует пласт работ, посвященных типологии ментальности. Исследуются чувственная и идеациональная (П.А. Сорокин) [15], этническая (М.И. Воловикова, Р.А. Додонов, Н.М. Лебедева, Л.Г. Почебут, Е.Н. Резников, А.Н. Татарко) [1], городская, провинциальная (Г.В. Акопов, Т.В. Иванова) [8], политическая (В.Ф. Петренко) [10], полиментальность (В.Е. Семенов) [14], роевая, ролевая, уединенная, конвергентная (В.И. Тюпа) [17], дописьменная, письменная и медиаментальность (В.А. Шкуратов) [18]. 
В концепции трех ментальных порядков В.А. Шкуратова [18] ментальность определяется как «человеческое измерение исторических макромасс или человеческая активность, объективированная в культурных памятниках» [19, с. 59]. В основе смены ментальных порядков лежит изменение способов мышления, особенностей коммуникации. Дописьменная ментальность первобытного общества, которая опирается на мистическое мышление и непосредственную коммуникацию. Письменная ментальность предполагает сосуществование иррационального и рационального мышления у субъектов. Сами коммуникаторы регулируют процесс коммуникации. Медиаментальность характеризуется тем, что коммуникация опосредуется передающими устройствами. Данный подход рассматривает ментальность широко без привязанности ее к определенному обществу [20].

Исходя из концепции полиментальности В.Е. Семенова [13, 14], полагаем, что в культуре находится большое разнообразие ментальностей. В.Е. Семенов определяет ментальность как исторически сложившееся групповое долговременное единство (сплав) сознательных и неосознанных ценностей, норм, установок в их когнитивном, эмоциональном и поведенческом выражении определенных слоев населения [13]. Он выделил в России коллективистско-социалистическую, западно-капиталистическую, православную, криминально-мафиозную и мозаичноконформистскую ментальность. Они на его взгляд подкрепляются культурноисторическимии социопсихологическими реалиями, фактами. На наш взгляд, автор наиболее близко подошел к решению вопроса связи социальной ситуации развития слоев населения и ментальности.

Перечисленные типологии ментальности охватывают следующие феномены, в которых репрезентируется ментальность: сознание, восприятие, интерпретация, идентификация, ценностные ориентации, установки, способы мышления и коммуникации, социальные представления, стратегии и характер взаимодействия коллективных субъектов. Два полюса ментальности у П.А. Сорокина [15] преобразовались в многосторонние типологии у других авторов. Мы полагаем, что исходными должны быть два полюса, таковыми для нас стали - традиции как форма социального наследования, связи и инновации как «форма отклонения, нонконформизма» (С. Московичи), а другие выступают их продолжениями. Таким образом, в основе лежат противоположности по С. Московичи процесса влияния как действия и противодействия [16].

В нашей типологии ментальности критериями различий явились параметры Я-концепции, значений образа мира, ценностей образа жизни, дискурса [11]. Сочетание их определило традиционную, переходную, инновационную и постинновационную ментальности. Наименование «традиционная ментальность» было принято по аналогии с утвердившимся в кросс-культурной психологии названием «традиционная культура». В традиционной культуре передача традиций, устоявшегося опыта жизнеустройства передается поколениям по прямой трансмиссии. «Инновационная ментальность» как противоположность традиционной, как инновационная культура, в которой трансмиссия традиции уже 
«непрямая» и сама традиция нивелируется. Традиция множится, перестает быть однозначной и однородной в период инноваций. Переходная и постиновационная ментальность - это переходные типы ментальности. В различные эпохи эти типы ментальности имеют различное содержательное наполнение. Основываясь на предыдущих исследованиях, можно полагать, что сегодня мы наблюдаем переходную эпоху в направленности трансформаций ментальности от коллективизма к индивидуализму.

\section{Методические основания исследования типов ментальности}

Различные методические основания представлены в работах $[1,2$, 3, 8, 9, 10, $13,17,19]$. Школа «Анналов» в начале XX века предложила свои методы историкокультурной реконструкции ментальности прошлых эпох $[4,5,7]$, развиваемые современными авторами [3, 19].

Г.М. Андреева, Г.Г. Дилигенский, Т.Г. Стефаненко и др. воссоздают «психологический облик» больших социальных групп [2], исследуя нравы, обычаи, продукты деятельности, язык, социальные представления, применяя методы этнографии, социологии, лингвистики, истории. Аналогичные методические основания для проведения социально-психологического исследования больших групп предлагают ввести Г.В. Акопов, Т.В. Иванова [8]. Авторы выделяют ментальности разного уровня субъектности. Исходя из этого, они предлагают сравнивать разные ментальности одного уровня субъектности (горизонтальные срезы).

Следующим возможным методическим основанием выступает применение психосемантических методов (Е.Ю. Артемьева, В.Ф. Петренко) [10].

Сегодня в решении проблемы ментальности утвердились психосоциальный, типологический и кросс-культурный подходы (К.А. Абульханова, А.Л. Журавлев, М.И. Воловикова, 2005) [1, 12]. Психосоциальный подход основан на том, что рассматриваются психические явления на социальном и психическом уровнях, при этом они рассматриваются во всей своей сложной взаимосвязи и отношениях, как системные, многомерные образования. К.А. Абульханова представляет типологический подход как процессуальный способ ее построения, когда очередной этап выдвигает совокупность методологических и теоретических вопросов. Она выдвигает две стратегии исследования целостности ментальности: изнутри парциальное исследование ее составляющих и извне - сравнительное исследование ментальности других обществ [1]. В.Е. Семенов посредством массовых опросов определяет долю того или иного типа ментальности среди населения [14]. Г.Л. Воронин представил авторскую методику измерения ментальности [6]. В качестве первичных эмпирических данных выступили оценочные реакции респондентов на афоризмы, максимы, пословицы. Это социологический подход в исследовании.

Основной методической проблемой изучения ментальности является то, что сам феномен ментальности довольно сложен и изучаются преимущественно ее отдельные составляющие (установки, ценности, представления), отдельные ее феномены. При этом теряется системная целостность ментальности. 


\section{Эмпирические данные}

Исследование было проведено в г. Ростове-на-Дону, г. Сальске (июнь 2006 г. май 2007 г.). Эмпирическую базу исследования представили большие социальные группы, дифференцированные относительно значимого социокультурного события - перестройка, в ходе которого сменился общественный строй, форма собственности. Выборку представляли следующие группы поколений: постсоветские 1990-95 гг. рождения (750 чел.); переходные 1980-85 гг.р., 1960-65 гг.р. (745 чел.) и советские 1940-1945 гг.р. (740 чел.). Постсоветские поколения, рожденные после перестройки - это основная, экспериментальная группа. Советские и переходные поколения, рожденные на границе между двумя эпохами - контрольная группа.

Применялся следующий методический инструментарий: Методика культурноценностного дифференциала (Г.У. Солдатова, И.М. Кузнецов, С.В. Рыжова); Шкала измерения социальных установок (Г.К. Триандис, 1995), Тест двадцати утверждений (М. Кун, Т. МакПартланд); Методика исследования представления человека о себе и других людях (Т. Лири, 2005); Методика исследования различных видов толерантности (М.С. Жамкочьян, В.С. Магун, М.М. Магура, 2000); Методика диагностики характеристик ментальности поколений (В.И. Пищик, 2006). Нами было выявлено, что у переходных поколений в культурно-ценностном дифференциале представлен горизонтальный индивидуализм с параметрами: душевность, разобщенность, самостоятельность, индивидуализм, недоверие к власти, традиционализм, коллективизм, своеволие, свободолюбие, анархия, холодность, соперничество, склонность к риску $(\mathrm{p}<0,05)$. В группе советских поколений выявлен конструкт горизонтального коллективизма, характеризующейся: взаимовыручкой, верностью традициям, открытостью, устремленностью в прошлое и в будущее, сердечностью, дисциплинированностью и уважением власти ( $<<0,05)$. Измерение социальных установок (шкала Г.К. Триандиса), показало, что в группе переходных и советских поколений преобладают установки, ориентированные на коллективизм, а в группе постсоветских поколений на индивидуализм.

Изучались представления о своем «Я». Выявлено, что большинство высказываний: 35 \% у переходных поколений и 40 \% у советских поколений - обладают признаками взаимозависимости от группы (социальные ответы по Г.К. Триандису). В них меньше представлены этнические и религиозные представления. Делается вывод о доминировании социальной надсистемы ментальности. В группе постсоветских поколений 60 \% высказываний независимых от группы. Из этого следует, что представления о своем «Я» в группе советских и переходных поколений коллективистской направленности, а в группе постсоветских поколений - индивидуалистической направленности $(\mathrm{p}<0,05)$.

Определена степень толерантности/интолерантности в отношениях между поколениями. Этническая толерантность у переходных поколениях получила самые низкие баллы. Выше среднего получила толерантность к сложности и неопределенности окружающего мира. Средние баллы получила толерантность к иным взглядам, толерантность отступления от общепринятых норм и неавторитаризм. В группе 
советских поколений низкие баллы были получены по толерантности отступления от общепринятых норм. Очень низкая толерантность выявлена к иным взглядам и неавторитаризм. Средние баллы были получены по этнической толерантности. Выше среднего получены баллы по толерантности к сложности и неопределенности окружающего мира. В целом результаты измерения видов толерантности в группе переходных и советских поколений, значимо различаются $(a<0,05)$. Что косвенно может быть предпосылкой их интолерантных отношений. По результатам методики Т. Лири переходное поколение в отношениях характеризуется властностью, неуступчивостью, упрямством и холодностью в отношениях, что подтверждает результаты исследования их культурно-ценностного дифференциала. Представители советского поколения в свою очередь более требовательны, уверены в себе, более отзывчивы, упрямы.

В результате применения авторской методики, было выявлено, что в группе переходных поколений инновационная ментальность обнаружена у 47 \%, переходная - у 27 \% и традиционная - у 23 \% человек, постинновационная у 3 \%. В группе советского поколения большинство имеет традиционную ментальность. Таким образом, наблюдается отход от традиций в среде молодого поколения.

В результате исследования было выявлено, что у советских поколений преобладает традиционная ментальность со следующими социально-психологическими характеристиками: взаимозависимыми представлениями о своем «Я», коллективистские ценности, направленностью на социальную стабилизацию, преобладанием конформизма в отношениях, дискурсивной гомогенностью. У постсоветских поколений преобладает инновационная ментальность со следующими социальнопсихологическими характеристиками: независимыми представлениями о своем «Я», индивидуалистические ценности, с направленностью на социальные изменения, дискурсивной гетерогенностью.

Таким образом, нами было проведено сравнение составляющих ментальности постсоветских поколений Южного региона России и советских поколений. В результате у советского поколения преобладает традиционный тип ментальности, а у постсоветских поколений - инновационный тип ментальности.

\section{Литература}

1. Абульханова К.А. Психология и сознание личности: избранные психологические труды. - М.: МПСИ; Воронеж: НПО МОДЭК, 1999.

2. Андреева Г.М. Психология социального познания. - М.: Аспект Пресс, 2000.

3. Барская А.Д. Особенности мышления гомеровского человека // Вестник МГУ.Сер. 14. Психология. - 1997. - С. 23-32.

4. Блок М. Апология истории или ремесло историка. - М.: Наука. 1973.

5. Бродель Ф. Структуры повседневности: возможное и невозможное // Материальная цивилизация, экономика и капитализм XV-XVII Вв. В 3 т. - Т. 1. - М.: Прогресс, 1986. 
6. Воронин Г.Л. Типология ценностно-нормативных ориентаций // Социологический журнал. - № 3. - 1995. - С. 151-158.

7. Дюби Ж. История ментальностей // Историческая антропология: Зарубежные исследования в обзорах и рефератах. - М.: РАН, Ин-т всеобщ. Истории и Рос. Гос. Гуманитарный ун-т, 1996.

8. Менталистика: проблемы, решение, перспективы исследований (ментальность поволжского социума в научных проектах). - Самара: СНЦ РАН - СамГПУ, 2001.

9. Методика «Менталитет» (С. Балабанова и Г.Л. Воронина) // Процессы идентификациии российских граждан в социальном пространстве «своих» и «несвоих» групп и сообществ (1999-2002 г.г.) Мастер-класс профессора В.А Ядова Методологический практикум для студентов социологов. - Москва, 2004. - С. 37-38.

10. Петренко В.Ф. Основы психосемантики. - М.: Изд. МГУ, 1997.

11. Пищик В.И. Трансформация ментальности: Системный подход. - Ростов-на-Дону: Изд.-во СКНЦ ВШ ЮФУ, 2007.

12. Российский менталитет: вопросы психологической теории и практики / Под ред. К.А. Абульхановой, А.В. Брушлинского, М.И. Воловиковой. - М.: «Институт Психологии РАН», 1997.

13. Семенов В.Е. Современная российская полиментальность и ментальные типы молодежи // Ментальность россиян провинции. Сборник материалов IV-ой Всероссийской конференции по исторической психологии российского сознания. 1-2 июля 2004 г. - Самара: Изд-во СГПУ, 2005. - С. 159-163.

14. Семенов В.Е. Типология российских менталитетов и имманентная идеология России // Вестник СПб ГУ. - Сер. 6. - 1997. - Вып. 4. - № 27. - С. 59-67.

15. Сорокин П.А. Кризис нашего времени // Человек. Цивилизация. Общество / Общ. ред., сост. и предисл. А.Ю. Согомонов: пер. с англ. - М.: Политиздат, 1992. - С. 427-488.

16. Социальная психология / Под ред. С. Московичи. - СПб.: Питер, 2007. - С. 64.

17. Тюпа В.И Диагностика ментального кризиса // Мир России. - № 1. - 2002. С. 153-165.

18. Шкуратов В.А. Искусство экономной смерти. Сотворение видеомира. - Ростовна-Дону: Наррадигма, 2006.

19. Шкуратов В.А. Историческая психология. - Ростов-на-Дону.: Город N, 1994.

20. Шкуратов В.А. Провинциальная ментальность десять лет спустя // Ментальность российской провинции. Сборник материалов IV-ой Всероссийской конференции по исторической психологии российского сознания. 1-2 июля 2004. - Самара: Изд-во СГПУ, 2005. - С. 82-92. 